\title{
O mordach rytualnych i sprawie Bejlisa ${ }^{1}$
}

\author{
tłumaczenie i komentarz - Zbigniew Cywiński (Warszawa)
}

\section{OD TŁUMACZA}

W 2017 roku przypada 150 rocznica urodzin Leona Petrażyckiego. Nie ma potrzeby, aby w tym miejscu obszerniej omawiać postać i dorobek wielkiego polskiego uczonego, którego dokonania nie tylko wpłynęły znacząco na kształt niemieckiej, rosyjskiej i polskiej nauki prawa jego czasu, ale do dnia dzisiejszego istotnie zaznaczają swoją obecność. Być może najwyraźniej widać to w kształcie polskiej socjologii prawa, w znaczącym stopniu ukształtowanej pod wpływem realistycznego ujęcia prawa Leona Petrażyckiego, jednak jego koncepcje zajmują też filozofów prawa, etyków, przedstawicieli doktryny prawa cywilnego etc. O ich żywotności świadczy nie tylko uznanie, ale i utrzymująca się od przeszło wieku skłonność do krytyk i polemik.

Warto jednak przypomnieć w tym miejscu celne pytanie, zadane jeszcze w 1932 roku przez Jerzego Landego: „Dlaczego nawet w Polsce, do której powrócił w r. 1919 i gdzie pracował ostatnie dwanaście lat życia, zmarł uznany wprawdzie za znakomitość, lecz tak mało znany?"’. Pytanie jest wciąż aktualne i nawet uproszczona próba odpowiedzi nie da się tu zmieścić. Można jednak wskazać na jeden z powodów, dziś znacznie ważniejszy niż w latach trzydziestych ubiegłego wieku. Petrażycki otóż, jakkolwiek z urodzenia i patriotyzmu był Polakiem, przynależał do trzech światów naukowych. Jego młodzieńcze prace, pisane po niemiecku, zdobyły mu pozycję w niemieckiej nauce prawa. Najważniejsze, spośród przezeń opublikowanych, były prace pisane i wydane w języku rosyjskim i ściśle związane z działalnością Petrażyckiego, jako wybitnego przedstawiciela nauki rosyjskiej, profesora Uniwersytetu Petersburskiego, którego pozycja i popularność wykraczała poza ramy tamtejszego Wydziału Prawa.

Powtarzając te oczywistości, trzeba pamiętać i przy ocenie recepcji dorobku Leona Petrażyckiego w Polsce mieć na uwadze, że czytelnik polski, nieznający rzeczywistego stanu rzeczy, sądzić może, że prace wydane w języku polskim stanowią Petrażycjanskie opera om-

${ }^{1}$ Wybrane fragmenty tego artykułu były wcześniej wydrukowane w 1913 roku w numerze 280 gazety „Riecz” (który był skonfiskowany ze względu na inny artykuł); por. też „Sowriemiennoje Słowo” 1913, nr 2070 i „Siewiero-zapadnyj gołos” 1913, nr 2539.

2 Cyt. za: Jerzy Lande, Leon Petrażycki, [w:] idem, Studia z filozofii prawa, Warszawa 1959, s. 584 [przyp. thum.]. 
nia, podczas gdy do dnia dzisiejszego dostęp do znaczącej części dorobku tego uczonego jest ograniczony. Objętość dzieł dotychczas nieprzetłumaczonych na język polskie przekracza trzy tysiące stron, obejmując ogół prac cywilistycznych i romanistycznych (w tym także tych, które opublikowano po niemiecku), szczegółowe studia odnoszące się do oficjalnego prawa rosyjskiego, prace odnoszące się do istoty nauki i roli uniwersytetów oraz wiele innych.

Kilkukrotnie podejmowano inicjatywy dotyczące polskiej edycji dorobku Leona Petrażyckiego, ale zarówno przedwojenne, podejmowane jeszcze za życia uczonego, jak i powojenne edycje, jakkolwiek objęły kilka prac podstawowych, trudno uznać za satysfakcjonujące. Można jedynie żywić nadzieję, że kolejna inicjatywa, inspirowana przez prof. Andrzeja Kojdera i nabierająca dziś kształtu na Wydziale Prawa i Administracji Uniwersytetu Warszawskiego, zostanie uwieńczona powodzeniem i pozwoli nie tylko objąć całokształt dorobku uczonego, ale też prześledzić rozwój jego naukowych pomysłów i idei.

Nie poznany do końca Petrażycki jest nierzadko postrzegany jako uczony oderwany od rzeczywistości, gabinetowy teoretyk snujący idee niemające znaczącego związku z otaczającą go rzeczywistością społeczną i prawną. Dopiero spojrzenie na prace niewydane pokazuje, że było inaczej. W okresie petersburskim istotną część jego publikacji stanowiły studia krytyczne odnoszące się do projektów prawodawczych i prawa obowiązującego, wprost nawiązujące do jego teorii.

Pozostając zawsze uczonym, nie stronił w Petersburgu od zaangażowania społecznego: posłował do I Dumy, podpisał Manifest Wyborski (za co został skazany na twierdzę), wspierał rosyjskie sufrażystki, czynnie uczestniczył w działaniach polskich organizacji społecznych i naukowych. Nietrudno dostrzec, że w swych działaniach społecznych kierował się ideałami równości i wolności, które odnaleźć można także w jego pracach naukowych.

Prezentowany niżej tekst leży na pograniczu nauki i zaangażowania społecznego. Traktuje o sprawie bieżącej, nie jest jednak wolny od aparatu naukowego. Odnosząc się do sprawy bulwersującej opinie i media, Petrażycki podejmuje wątki krytycznej analizy źródeł historycznych i wkracza w domenę współcześnie nazywaną socjologią kryminalistyczną. Zetknięcie się zaangażowania obywatelskiego z przynależnym nauce obiektywizmem przynieść może różne efekty. Można mieć nadzieję, że uprzystępnienie w języku polskim artykułu o „sprawie Bejlisa” pozwoli czytelnikowi dowiedzieć się więcej o Leonie Petrażyckim i osądzić, jak uporał się z tym problemem.

Określenie „sprawa Bejlisa” w wąskim rozumieniu odnoszone jest do procesu [Menachema] Mendla Bejlisa, oskarżonego o dokonanie mordu rytualnego na Andrzeju Juszczyńskim. W szerszym znaczeniu oznacza związane z procesem i daleko wykraczające poza granice ówczesnego Imperium Rosyjskiego poruszenie społeczne, odbijające się do czasów współczesnych nie tylko w sporach naukowych, ale też w literaturze i publicystyce odnoszącej się czy to do „wschodnioeuropejskiego antysemityzmu”, czy też do ,żydowskiego zagrożenia”.

Sprawę rozpoczęło zaginięcie, a następnie zamordowanie trzynastoletniego ucznia gimnazjalnej Kijowsko-Sofijskiej Szkoły Duchownej. Andrzej Juszczyński zaginął 12 marca (starego stylu) 1911 roku, a jego ciało, naznaczone blisko pięćdziesięcioma ranami kłutymi, zostało odnalezione po ośmiu dniach. Jakkolwiek pogłoski o rytualnym charakterze zabójstwa, wiązanego ze świętem Paschy, pojawiły się bezpośrednio po odnalezieniu zwłok, to w początkowej fazie śledztwo koncentrowało się na najbliższej rodzinie ofiary i powiązaniach przestępczych Wiery Czerebiak, matki towarzysza zabaw Juszczyńskiego. W jej zeznaniach pojawiło się pierwsze zapisane w dokumentach sprawy oskarżenie żydów. Po odsunięciu od sprawy lokalnych śledczych wątek morderstwa rytualnego stopniowo stawał się pierwszoplanowy, a 22 lipca pod zarzutem dokonania mordu rytualnego został aresztowany Mendel Bejlis, pracownik cegielni, sąsiadującej z miejscem odnalezienia zwłok. 
Postępowanie w jego sprawie (a w konsekwencji proces sądowy) nie tylko przyciągnęło zainteresowanie prasy i publiczności zagranicznej, ale też doprowadziło do polaryzacji rosyjskiej opinii publicznej. Z jednej strony znaleźli się zwolennicy tezy procesowej (streszczającej się do oskarżenia o mordy rytualnie nie żydów w ogólności, ale sui generis sekty, do której Bejlis miał należeć), z drugiej zaś rosyjska lewica i liberałowie. Pod opublikowanym w gazecie „Riecz” Apelem do społeczeństwa rosyjskiego, przestrzegającym przed uleganiem fobii antysemickiej, podpisali się między innymi Władimir Korolenko (prawdopodobnie autor Apelu...), Aleksander Błok, Maksym Gorki, Piotr Struwe, Maksym Kowalewski, Jan Baudouin de Courtenay, Tadeusz Zieliński i Leon Petrażycki. Wszczęto „śledztwo obywatelskie”, które miało za zadanie dostarczenie dowodów obronie, a brali w nim udział śledczy odsunięci od śledztwa oficjalnego. Mnożyły się publikacje, wystąpienia i ulotki przedstawiające racje jednej lub drugiej strony.

W takiej atmosferze toczył się proces, w którym sprzecznym ekspertyzom i dowodom towarzyszyły wzajemne oskarżenia o przekupstwo świadków, korupcję, uleganie naciskom, stronniczy dobór dowodów świadków i przysięgłych itd.

Po przeprowadzeniu postepowania zadano przysięgłym dwa pytania. Pierwsze dotyczyło samego faktu zabójstwa, jego sposobu i miejsca, drugie odnosiło się do winy Bejlisa. Wyrok zapadł 28 października 1913 roku. Bejlis został uniewinniony, jednakże twierdząca odpowiedź przysięgłych na pierwsze pytanie (na które nie można było udzielić odpowiedzi cząstkowej, np. potwierdzającej zabójstwo, ale podważającej tezy oskarżenia co do formy i miejsca) po dziś dzień bywa przedstawiana jako potwierdzenie mordu rytualnego.

Kwestia sprawstwa pozostała nierozstrzygnięta.

Artykuł Petrażyckiego ukazał się pierwotnie w tygodniku „Prawo” (L[ew] I[osifowicz] Pietrażyckij, O ritualnych ubijstwach $i$ diele Biejlisa, „Prawo. Jeżeniedielnaja juridiczeskaja gazieta" 1913, nr 42, s. 2403-2423, a następnie nakładem autora jako samodzielna broszura (prof. L[ew] I[osifowicz] Pietrażyckij, O ritualnych ubijstwach i diele Biejlisa, Tipografiia t-wa „Obszczestwiennaja Polza”, S.-Pietierburg 1913.

Pragnę podziękować pani Ewie Pajestce-Kojder za nieocenioną pomoc redakcyjną.

Zbigniew Cywiński

Należy rozpocząć od zastrzeżenia co do treści poniższego szkicu.

Jakkolwiek w związku z prowadzonymi przeze mnie badaniami dotyczącymi rozwoju prawa, w szczególności zaś prawa sakralnego, zdarzało mi się mieć do czynienia z problematyką mordów rytualnych, nie jest moim zamiarem przywoływanie własnego dorobku w tej dziedzinie ani też racji przemawiających za odrzuceniem legendy o istnieniu w religii żydowskiej nakazu użytkowania krwi pochodzącej od chrześcijan (ujmując rzecz ściślej: o obecności w żydowskim prawie sakralnym normy, która nakazywałaby wykorzystywanie krwi chrześcijańskiej). Legendę taką dawno już poddano weryfikacji naukowej i odrzucono w sposób, który nie może budzić i nie budzi żadnych wątpliwości w kręgach naukowych. W nauce i dla nauki problem taki nie istnieje, sama zaś legenda może skupiać jedynie zainteresowanie 
psychologii jako swoiste zjawisko psychologii zbiorowej, niejednokrotnie pojawiające się w przeszłości i kierowane pod adresem różnych innowierców, a jak wiadomo, także pod adresem chrześcijan. Pojawiało się ono pośród ciemnych i kulturowo zapóźnionych mas ludowych obok różnych innych, niekiedy nawet bardziej niedorzecznych i fantastycznych legend i przesądów. W związku z osławioną sprawą Bejlisa, która urosła do rangi ogólnoświatowego skandalu, w tych kwestiach wypowiedziało się tak wielu cieszących się autorytetem i kompetentnych przedstawicieli nauki świeckiej i duchownej, historyków, filologów, teologów, zgodnie i stanowczo potwierdzających takie właśnie stanowisko nauki, bezpodstawność i niedorzeczność krwawej legendy, że mój, dość skromny w porównaniu z nimi, autorytet naukowy stanowi quantité négligeable i do tak znaczącej wagi argumentów i autorytetu naukowego nic znaczącego dodać by nie mógł.

Nie można jednak pozwolić, aby w związku z tym uszedł uwadze osobliwy zamysł, polegający na tym, że do rozstrzygnięcia dawno już przez naukę rozstrzygniętego problemu dopuszcza się, w celu pozyskania odmiennej opinii, dopytywanie o osobiste przekonania $\mathrm{w}$ tej kwestii bliżej nauce nieznanego i niekompetentnego naukowo litewskiego księdza Pranajtisa ${ }^{3}$, który występuje w tym bardziej wątpliwej roli, że staje w opozycji i wypowiada wojnę nie tylko nauce i jej autorytetowi, ale też Kościołowi katolickiemu, wypowiadając się jako jego członek ku goryczy innych, dostojniejszych i bardziej oświeconych jego przedstawicieli.

Jeśli uznać za dopuszczalne w postępowaniu procesowym i nazwać „ekspertyzą" takie sposoby rewidowania rozstrzygniętych problemów naukowych, to

3 Justyn Bonawentura Pranajtis (1862 - 1917), ksiądz katolicki, magister teologii. Prefekt i wykładowca języka hebrajskiego w Rzymskokatolickiej Cesarskiej Akademii Duchownej w Sankt Petersburgu. Przeniesiony dyscyplinarnie do Tweru, a następnie do Taszkientu. Zwolennik i propagator poglądów o antychrześcijańskiej treści Talmudu i religijnym umocowaniu mordów rytualnych. Ekspert oskarżenia w procesie Bejlisa.

Autor pracy Christianus in Talmude Iudaeorum sive Rabbinicae doctrinae de Christianis secreta, wydanej w Sankt Petersburgu w 1892 roku. Poza wydaniem łacińskim ukazało się wówczas także wydanie w języku polskim (Chrześcijanin w Talmudzie żydowskim, czyli tajemnice nauki rabinów o chrześcijanach, które ujawnit J.B. Pranajtis, 1892). W 1894 roku ukazało się w Wiedniu thumaczenie na język niemiecki. Na fali zainteresowani sprawą zabójstwa Andrzeja Juszczyńskiego praca została przetłumaczona na język rosyjski, litewski i kilka innych języków europejskich, zazwyczaj w skróconej postaci. Poza Polską nie jest wznawiana.

Ocena zarówno tej pracy, jak i wystąpień (także procesowych) księdza Pranajtisa nie jest jednoznaczna i zależy ściśle od stanowiska przyjętego przez krytyków w kwestii żydowskiej. Pranajtis przedstawiany jest bądź jako wybitny znawca Talmudu, bądź też jako hochsztapler o słabej znajomości pojęć podstawowych. Jego obecność na procesie tłumaczona jest wyjątkową kompetencją albo też pilną (wobec oporu specjalistów ze środowisk akademickich i cerkiewnych, skłonnych raczej występować na rzecz obrony) potrzebą znalezienia eksperta gotowego popierać antysemickie zarzuty.

Przed śmiercią Pranajtis miał wyrazić podejrzenie, że został otruty [przyp. thum.]. 
można bez ograniczeń inscenizować dowolne niedorzeczne i fantastyczne procesy. Skoro dopuszcza się i nazywa „zeznaniami świadków” kwestionowanie rozstrzygniętych problemów naukowych przez osoby, które żadnego związku ani ze sprawą jako świadkowie, ani z nauką nie mają, to czym się stanie sądownictwo karne! Nawet w epoce średniowiecznego mroku, kiedy możliwe i praktykowane były takie procesy, podobne przejawy „ekspertyzy” i ,zeznań świadków” zostałyby uznane za coś osobliwego i niedopuszczalnego.

Nie uważam zatem, aby racjonalne było ponowne badanie omawianego tu, od dawna w nauce rozstrzygniętego, problemu. Jeśli uznałem wypowiadanie się w niektórych kwestiach związanych ze sprawą Bejlisa za właściwe czy nawet moralnie nieodzowne, to ze względu na obecność pewnych poglądów z innej dziedziny, na które należałoby zwrócić uwagę, by uniknąć możliwej pomyłki sądowej, mogącej prowadzić do fatalnych dla obydwu spierających się stron konsekwencji (mam tu na myśli, oczywiście, nie strony procesowe, ale coś niepomiernie większego i ważniejszego).

Moje poglądy nie odnoszą się do sfery zabytków i dokumentów historycznych oraz religijnych ani też do ich naukowo-technicznego badania, ale lokują się w skromnym polu zwykłej ludzkiej logiki i roztropności. Powinny być, jak sądzę, jasne i zrozumiałe dla wszystkich przeciętnych ludzi, nie zajmujących się nauką, ale pozostających ,przy zdrowych zmysłach i dobrej pamięci”"

Przede wszystkim, tytułem wstępu, pozwolę sobie zaprezentować pewne, skromne, jak wspomnieliśmy, ogólne poglądy.

Przyjmijmy, że ksiądz Pranajtis czy też jakikolwiek inny jegomość z takiej lub innej przyczyny jest bardziej miarodajny niż nauka ze wszystkimi swoimi cieszącymi się uznaniem i światłymi przedstawicielami, jemu zatem należy bardziej dowierzać (choćby to było sprzeczne ze zdrowym rozsądkiem). W takim razie, jeśli się uwierzy, że w Starym Testamencie, Talmudzie lub im podobnych można znaleźć stosowny nakaz rytualny, nakaz prawa sakralnego, nie trudno w wyniku kilku całkiem prostych refleksji dojść do wniosku, że taki nakaz w praktyce nie działa, że (podobnie jak różnorodne dawne nakazy, rzeczywiście istniejące, ale niedostosowane do zmienionych warunków życia, trudne do wypełnienia itd.) został zneutralizowany i osłabiony przez odpowiednią interpretację itp., w każdym zaś razie w istocie rzeczy został pozbawiony mocy sakralno-prawnej i nie jest przestrzegany.

\footnotetext{
${ }^{4}$ Sformułowanie użyte przez autora: „W zdrawom umie i twierdoj pamiati”, stanowiło przyjęte w przedrewolucyjnej Rosji wprowadzenie do przysięgi sądowej [przyp. tłum.].
} 
Przede wszystkim, gdyby taki nakaz religijny istniał, był uznawany za wiążący i jako taki przestrzegany, to w czasie żydowskiej Paschy w różnych częściach kuli ziemskiej, w szczególności w różnych miejscowościach europejskich dochodziłoby regularnie do zaginięć dzieci chrześcijańskich, zaginięć, które by miały charakter, by tak rzec, systematycznie i metodycznie rokrocznie powtarzającego się osobliwego zjawiska - tak jak to wynika z natury rytuału religijnego. Musiałoby to wyjść na jaw, podobnie jak okoliczność, że takie osobliwości nie występują w krajach, w których nie ma żydów, że liczba takich dziwnych faktów zależy od liczebności ludności żydowskiej itd. W takiej sytuacji sama statystyka musiałaby ujawnić takie zjawiska i wyjaśnić ich sens.

W rzeczywistości nic takiego nie występuje, a zatem brakuje samego już zewnętrznego faktu, który można by wyjaśnić skrytymi działaniami żydów, podejmowanymi w złej intencji. Istnieją rozmaite przesądy ludzkie, które mają przynajmniej podstawę faktyczną w tym sensie, że odnoszą się do faktów, jakkolwiek dają im błędne, z niewiedzy wzięte objaśnienia. Tu mamy wszakże do czynienia z nierozumnością do kwadratu - z niewiedzy wzięta teoria służy do objaśniania faktów, które w rzeczywistości nie istnieją.

\section{III}

Idźmy dalej. Gdyby odpowiednia norma sakralna istniała i działała, to rzecz nie sprowadzałaby się do samego tylko tajemniczego znikania chrześcijańskich dzieci, łkań rodziców, dochodzeń prowadzonych przez władze i uczonych itp., ale mielibyśmy do czynienia z długim ciągiem przyczynowo-koniecznych następstw innego rodzaju.

Przede wszystkim niewątpliwie zachodziłoby i ujawniało się co następuje: jeśli wziąć pod uwagę, przykładowo, tylko ostatnich 500 lat, to ogólna liczba ofiar rytuału jako takiego musiałaby być ogromna, ogólna liczba zabójstw dokonywanych na przestrzeni wieków złożyłaby się na niebotyczną sumę. Skuteczne ukrywanie tak wielkiej liczby zabójstw byłoby zupełnie niewiarygodnym cudem. Gdyby przyjąć, że na 100 przypadków w 90 udawałoby się ukryć takie przestępstwo - co samo w sobie już jest niewiarygodne, jak można się przekonać już choćby z odpowiednich statystyk - albo nawet dopuścić, że takie czyny dałoby się ukryć w 98 czy nawet w 99 przypadkach na 100, to nieuchronnie liczba wykrytych i udowodnionych mordów rytualnych i tak byłaby znacząca.

Tymczasem, powtórzę, w rzeczywistości nic takiego nie zachodziło i nie zachodzi.

W historii znajdujemy liczne, potwierdzone przez szanowanych i nieposzlakowanych świadków, niekiedy przez wielu takich świadków, przypadki pojawiania się między żywymi osób zmarłych i temu podobnych cudów. Natomiast przy- 
padków, w których dokonywanie przez żydów mordów rytualnych na dzieciach chrześcijańskich poświadczono by w najmniejszym choćby stopniu, w skromniejszej choćby niż przy pojawianiu się zmarłych formie, nie tylko nie ma wielu, ale $\mathrm{w}$ istocie w całym biegu historii nie ma ich w ogóle.

Można więc powiedzieć, że los w tym wypadku żydom sprzyja, bo przecież, z wiadomych i naturalnych przyczyn, znanych nauce i przez nią wyjaśnionych (których objaśnienie tutaj zajęłoby zbyt wiele miejsca, a wydaje się zbędne), nierzadko się zdarza, że ludzie - w pełni godni szacunku i rzetelni - świadczą, z pełnym przekonaniem co do prawdziwości swoich zeznań, że widzieli, słyszeli itp. coś, czego w rzeczywistości nie było. $Z$ tej racji zdarzało się i wciąż zdarza skazywanie niewinnych z pełnym i powszechnym przekonaniem o bezsporności i całkowitym potwierdzeniu zarzucanego im czynu, który w rzeczywistości nie został popełniony.

Gdyby takie, całkiem możliwe i naturalne, zjawisko wystąpiło choćby kilka razy, czy choćby raz, w odniesieniu do procesów o mordy rytualne, to konsekwencje dla całego narodu żydowskiego byłyby prawdziwie groźne. Można pogratulować temu nieszczęsnemu ludowi, że przynajmniej to nieszczęście go ominęło.

O krwawym oszczerstwie można powiedzieć, że nie znajduje ono wsparcia nawet $\mathrm{w}$ takich przypadkach potwierdzenia w zeznaniach niezawisłych świadków itd., jakie można znaleźć względem pojawiania się zmarłych i rozmaitych innych niebywałych zjawisk.

Powtórzę i podkreślę to raz jeszcze: gdyby w rzeczywistości istniał taki rytuał, to nieuchronnie prowadziłby do wielości, do ogromnej liczby przypadków pełnego i rzeczywistego, nie zaś tylko pozornego, potwierdzenia mordów rytualnych, nawet przy założeniu, samym w sobie niewiarygodnym i nie dającym się pogodzić z danymi statystyki kryminalnej, możliwości ukrycia przestępstwa w 99 przypadkach na 100.

Także procesy o mord rytualny, niezależnie od istnienia swoistego zabobonu, a zatem siły psychicznej, od dawien dawna wzmacniającej powstawanie odnośnych, konkretnych podejrzeń, wpływającej na kierunek prowadzenia wstępnych dochodzeń, dobór i interpretację poszlak itd., są stosunkowo rzadkie, w przodujących zaś, wysoko rozwiniętych kulturowo krajach odeszły do krainy historycznych wspominków o minionym barbarzyństwie, wraz z (licznymi w swoim czasie) procesami czarownic, obwinianych o obcowanie płciowe z diabłami itp.

\section{IV}

Procesy takie $\mathrm{i}$ ich historia są ze swej strony $\mathrm{w}$ wielu aspektach bardzo pouczające. Fakty z dziejów procesów rytualnych powiedziałyby wiele interesujących rzeczy dociekliwemu badaczowi, potrafiącemu wyciągać z nich właściwe wnioski i zmusić je do ujawnienia swojej prawdziwej natury, uwarunkowań itp. 
W szczególności już same te fakty, niezależnie od innych danych, w tym także niezależnie od przywołanych wyżej argumentów, z pełną naukową jasnością i wiarygodnością pokazałyby takiemu badaczowi więcej niż to tylko, że kierowane przeciwko żydom oskarżenia są tak samo bezpodstawne, jak procesy przeciwko wiedźmom i czarownikom czy też wytaczane kogutowi za to, że zniósł jajo, z czego miało wynikać, że pozostawał w przestępczych konszachtach z siłą nieczystą (bywały i takie procesy!) itp. Oprócz tego ujawniałyby rzeczywiste podłoże i psychologię (nader paskudną) zarówno oskarżeń, jak i oskarżycieli.

Założenia i cele tego artykułu wykluczają, co oczywiste, podejmowanie w tym miejscu takich badań. Jednakże nawet tutaj na pewne kwestie można zwrócić uwagę, choćby w formie krótkich zaleceń dla przyszłych (wielce pożądanych) prac badawczych tego rodzaju.

Temu, kto podjąłby się takich badań, rekomendowałbym zwrócenie uwagi przede wszystkim na treść oskarżeń, które w różnym czasie i w różnych krajach kierowano bądź to wobec poszczególnych oskarżonych żydów, bądź też wobec żydów w ogóle, na czyny, które im zarzucano i dzięki torturom, wymuszonym samooskarżeniom albo gorszym jeszcze działaniom udowadniano.

Czego w istocie dotyczą takie oskarżenia?

Czytelnika być może zdziwi samo ujęcie powyższego pytania. Jak to, czego? Wiadomo, czego! Tego właśnie, o co teraz oskarżają Bejlisa (a tym samym żydów), to znaczy zabijania dzieci chrześcijańskich przez szczególne ich udręczenie (którego opisywanie byłoby zarazem przykre i zbędne) itd.

$\mathrm{W}$ istocie rzeczy pytanie takie nie jest ani błahe, ani bezcelowe. Przeciwnie jest wyjątkowo uzasadnione i ważne. Dla tych, którzy chcą być dobrze obeznani w tej sprawie, jest na tyle istotne, że dotychczasowym badaczom problematyki mordów rytualnych trzeba wytknąć, iż nie poświęcali temu aspektowi sprawy należytej uwagi i nie wyciągnęli odpowiednich wniosków.

Przede wszystkim przywołane wyżej jako uwagi czytelnika poglądy czytającej i nieczytającej publiczności opierają się na nieporozumieniu. To, co zrobili przestępcy z Juszczyńskim i co zarzuca się Bejlisowi, nie zdarzało się dawniej, i to nie tylko w rzeczywistości, ale nawet w wyobraźni ówczesnych oskarżycieli. Można powiedzieć, że jest to nowa konstrukcja, choć przedstawiana jako opis działania zgodnego $\mathrm{z}$ dawnym rytuałem. Także to, co opisuje-fantazjuje $\mathrm{w}$ tej kwestii znana szarlatańska praca Lutostańskiego ${ }^{5}$, odnosi się do dziedziny no-

${ }^{5}$ Autorowi szło prawdopodobnie o: I[ppolit] Lutostanskij, Żydy i ritualnyja ubijstwa hristianskich mładiencew. Uczenoje bogosłowsko-juridiczeskoje izseledowaniie, Tipo-litografiia t-wa „SWIET”, SPB [Sankt Petersburg] 1911 (Żydy i zabójstwa rytualne chrześcijańskich młodzieńców. Naukowe studium teologiczno-prawnicze) [tłumaczenia tytułów prac niewydanych w języku polskim pochodzą od tłumacza].

Pochodzący z polskiej rodziny autor, Hipolit Lutostański, były augustianin, wykluczony ze stanu duchownego ze względu na zarzuty natury politycznej i obyczajowej, był jednym z najbardziej 
wych wynalazków, choć powinno być przedstawieniem kształtu dawnego rytuału. W przeszłości bowiem, w różnym czasie i w różnych krajach, oskarżano żydów i - za pomocą tortur itp. - udowadniano im popełnienie czynów zupełnie niepodobnych do teraz im przypisywanych.

Wyliczanie w tym miejscu tego wszystkiego nie jest dla moich celów potrzebne (ani możliwe). Trzeba jednak zaznaczyć, że czyny, które leżały u podstaw oskarżania i skutecznego (z perspektywy celów, jakie wyznaczali sobie oskarżyciele) demaskowania żydów, cechuje wyjątkowa pstra mozaikowość i wielkie zróżnicowanie co do wymiarów i kierunków.

I tak, dla przykładu, jeśli idzie o przestępcze zabiegi dotykające ofiar, to szukając w przeszłości nie znajdziemy takich jak te, których dopuścili się przestępcy na ciele Juszczyńskiego. W dawnych oskarżeniach sądowych i innych źródłach można znaleźć natomiast opis wielu innych, wzajemnie się od siebie różniących zabiegów: ukrzyżowanie, toczenie $\mathrm{w}$ beczce $\mathrm{z}$ gwoździami, krojenie, dźganie, cios w określony punkt na karku, mający na celu utoczenie krwi itd. itp. Większą lub mniejszą rolę odgrywają przy tym ceremonie towarzyszące, ze swej strony także odmiennie przedstawiane w poszczególnych oskarżeniach i opisach: dopełnienie obrzędu obrzezania, obcinanie paznokci itp.

Dokładnie tak samo zróżnicowane są pozostałe okoliczności i przesłanki.

Jeśli rzecz dotyczy, przykładowo, wieku ofiary, to waha się on od niemowlęctwa do wieku starczego ${ }^{67}$. Dokładnie tak samo zróżnicowane są warunki

znanych antysemitów ówczesnej Rosji. Stopień naukowy uzyskał za pracę Wopros ob upotrieblenii jewriejami-siektatorami christianskoj krowi dla rieligioznych celej (Kwestia wykorzystywania przez żydów-sekciarzy krwi chrześcijańskiej w celach religijnych), którą mimo zarzutów plagiatu i niekompetencji rozwijał i pod zmieniającymi się tytułami doprowadził do wersji siedmiotomowej. W międzyczasie, pod presją ostracyzmu publikował też samokrytyki własnych poglądów. Wspomniana publikacja była jedną z wielu oskarżających żydów o mordy rytualne, które ukazały się przy okazji sprawy Bejlisa [przyp. thum.].

${ }^{6}$ Nawiasem mówiąc, w jednym z oficjalnych śledztw, podjętych przez władze rosyjskie w 1816 roku, ważną rolę w różnych instancjach, w tym także w Senacie Rządzącym, odegrały zeznania złożone przez wychrzczonego Żyda, który wraz z rozmaitymi opisami, objaśnieniami itp. złożył oświadczenie, że porwany chrześcijanin, choćby był osiemdziesięcioletnim starcem, zabijany jest tego samego dnia, w którym go porwano itd. Por.: D[aniił] A[wraamowicz] Chwolson, O niekotorych sriedniewiekowych obwinienijach protiw jewriejew. Istoriczeskoje issledowanije po istocznikam, wyd. 2 zm., Tip. Cedierbauma i Goldienbluma, S.-Pietierburg 1880, s. 202 (O niektórych średniowiecznych oskarżeniach żydów. Historyczne badanie źródeł).

${ }^{7}$ Przywoływany w przypisie przez Petrażyckiego Daniel Abramowicz Chwolson (1819 - 1911) to rosyjski hebraista, orientalista i historyk pochodzenia żydowskiego. Po otrzymaniu wstępnego wyksztalcenia w wileńskich szkołach żydowskich kontynuował naukę na uniwersytetach niemieckich. Po otrzymaniu stopnia doktora powrócił do Rosji i przeszedł na prawosławie. Profesor Uniwersytetu w Sankt Petersburgu i Sankt Petersburskiej Prawosławnej Akademii Rosyjskiej Cerkwii Prawosławnej, wykładowca Imperatorskiej Rzymskokatolickiej Akademii Duchownej w Sankt Petersburgu. Członek korespondent Imperatorskiej Rosyjskiej Akademii Nauk. Poza licznymi pracami 
i przesłanki, dotyczące przedmiotu rytuału; jego podmiotów, ich liczebności od całkiem nielicznych uczestników poprzez coraz to liczniejszych aż do publicznego zgromadzenia gminy żydowskiej w synagodze, czy też zbiórki pieniężnej od wszystkich członków gminy, włączając dzieci, które przekroczyły czternasty rok życia, na dokonanie zamierzonego czynu itp.; miejsca (synagoga lub inne); czasu itd. itp.

Jeśli idzie o pozyskiwanie krwi chrześcijańskiej, to poszczególne elementy rytuału związane z krwią, są odmiennie przedstawiane w poszczególnych oskarżeniach i dowodach. Krew może służyć do namaszczania rąk kapłanów, błogosławiących lud w synagogach, do pomazania innych przedmiotów, może być wypijana wraz z innymi napojami, spożywana jako specjalna potrawa bądź też dodawana do potraw: do ciasta przaśników paschalnych albo do jaja używanego w ceremonii ślubnej itd.

Co więcej, wahania i różne odmiany dotyczą także tego, czy krew pozyskiwana jest i używana do celów rytualnych, do wypełnienia nakazów rytualno-religijnych czy też służy innym celom. Jeśli zaś o te inne cele idzie, to także tutaj występują rozmaite warianty, zgodnie z którymi krew może być używana do zabiegów czarodziejskich, kosmetycznych albo medycznych. Jeśli idzie o choroby leczone krwią chrześcijańską, to również one są różnorodne, a wśród nich są i takie, których istnienie może potwierdzić jedynie ekspertyza zgodna z oskarżeniami żydów i sprzeczna z nauką, jak choćby menstruacja u żydów płci męskiej.

Wskazane przykłady różnorodnych wariantów oskarżeń i dowodów, zmiennych w przedstawionych wymiarach i kierunkach (a także różnych innych), bynajmniej nie stanowią nowych odkryć historycznych przez mnie dokonanych. Przeciwnie - są one powszechnie znane badaczom tych zagadnień. Podane przykłady, tak jak i wiele innych, choć zwykle mają charakter marginalnych i rozproszonych

naukowymi (dotyczącymi głównie orientalistyki, biblistyki, judaistyki i wczesnego chrześcijaństwa) oraz translatorskimi (był thumaczem obszernych fragmentów Starego Testamentu) opublikował też wiele prac popularyzatorskich i polemicznych, skierowanych przeciwko antysemityzmowi.

Problematyką mordów rytualnych zajmował się od 1857 roku, kiedy to wszedł w skład specjalnej komisji powołanej przez Aleksandra III do zbadania źródeł historycznych w tej kwestii. Było to związane z oskarżeniem w Saratowie grupy żydów o mordy rytualne. Jakkolwiek komisja nie potwierdziła istnienia jakichkolwiek wiarygodnych historycznych źródeł w tej materii, to jej opinia nie wpłynęła na wcześniej zakończone postępowanie, w którym zapadły wyroki skazujące.

Chwolson zmarł trzy dni po odnalezieniu w Kijowie zwłok Andrzeja Juszczyńskiego [przyp. thum.].

${ }^{8}$ „I tak, węgierski historyk Anton Bonfinius (Anton Bonfinius, Rer. Hung. Dec. V. I. III., fol. 78) powiada, że u żydów nie tylko kobiety, ale i mężczyźni dotknięci są krwawieniem miesięcznym, z której to choroby leczą się krwią chrześcijan. Któż mógłby w to wątpić, skoro w Trnawie (Tyrnau) w roku 1494 kilku starych żydów, ma się rozumieć podczas tortur, przyznało się do tego i skoro W następstwie tego przyznania 14 żydów (2 kobiety i 12 mężczyzn) spalono żywcem?" (tamże, s. 218). 
wzmianek, można spotkać na każdym kroku w literaturze poświęconej mordom rytualnym: w pracach zarówno przeciwników legendy, jak i jej zwolenników; zarówno w poważnej literaturze naukowej (jak choćby w cytowanym, wybitnym i wyjątkowo wyczerpującym studium profesora Chwolsona), jak i w dziełach szarlatańskich (Lutostańskiego i jemu podobnych). Z tej racji można nie obciążać wywodu nagromadzeniem kolejnych wypisków i cytatów. Warto za to przytoczyć tutaj dość krótki i syntetyczny przegląd oskarżeń kierowanych wobec żydów. Zestawiony (dla innych celów) przez profesora Chwolsona i przedstawiony we „Wprowadzeniu” do jego pracy:

„Oskarżenie głosi, że żydzi kradną dzieci chrześcijańskie, zabijają je i wykorzystują ich krew. W jakim jednak celu to robią i do czego tej krwi używają? w tej kwestii stanowiska oskarżycieli nader się różnią. Wszystkie takie stanowiska można jednak zasadniczo podzielić na dwie klasy, a mianowicie: a) stwierdzające, że żydzi wykorzystują krew do celów religijnych i b) stwierdzające, że wykorzystują ją do czarów, celów medycznych lub dowolnych innych przesądnych celów. Do pierwszej klasy przynależą, z grubsza rzecz biorąc, następujące stanowiska:

1) żydzi używają jakoby krwi chrześcijańskiej do przygotowania paschalnych przaśników i dodają ją do wina, które piją w pierwsze dwa wieczory Paschy;

2) chrześcijańska krew jest wykorzystywana w ceremonii ślubnej: gdy pan młody i panna młoda, stojąc pod baldachimem, przyjmują błogosławieństwo, wówczas jakoby rabin podaje im krew chrześcijańską zmieszaną z jajkiem;

3) kapłani żydowscy namaszczają sobie krwią ręce, błogosławiąc w synagogach lud, zgodnie z Księgą Liczb (6: 24 i nast.);

4) w święto Haman (Purim) rabini posyłają członkom swojej wspólnoty danie przygotowane z krwi chrześcijańskiej;

5) żydzi mają nadzieję, że ofiara z krwi chrześcijańskiej będzie miła Bogu, czy też: żydzi uważają krew chrześcijańską za miłą Bogu, ponieważ po zburzeniu Świątyni nie mogą składać ofiar, mimo że obowiązek składania ofiar, w przekonaniu oskarżycieli, nie został zniesiony;

6) zabijane dziecko chrześcijańskie zastępuje jagnię paschalne;

7) żydzi mażą w Paschę drzwi krwią chrześcijańską na pamiątkę pomazania drzwi krwią paschalnego jagnięcia w czasach wyjścia z Egiptu;

8) kiedy żyd umiera, jego współwyznawcy maszczą mu twarz krwią albo zanurzają w niej chustę, którą następnie kładą na twarz zmarłego, rzekomo mówiąc mu przy tym do ucha: «jeśli ów Mesjasz, w którego wierzą chrześcijanie i na którego liczą, jest prawdziwym, przepowiedzianym Mesjaszem, to niech ta krew niewinnie zabitego chrześcijanina pomoże ci osiągnąc życie wieczne»;

9) niektórzy twierdzą, że żydzi nie używają krwi wykradzionych przez siebie niemowląt, ale krzyżują je w Wielki Piątek, aby w ten sposób corocznie odtworzyć ukrzyżowanie Jezusa Chrystusa; i w końcu - 
10) żydzi zabijają dzieci chrześcijańskie z samej tylko nienawiści do chrześcijaństwa.

Do drugiej klasy odnoszą się następujące stanowiska, prezentowane przez oskarżycieli żydów:

11) żydzi wykorzystują krew chrześcijańską w nieznanych celach medycznych;

12) żydzi wykorzystują krew chrześcijańską, aby zagłuszyć jakoby swoisty im smród;

13) żydzi przygotowują z krwi chrześcijańskiej rozmaite mikstury pobudzające miłość;

14) żydzi wykorzystują taką krew, aby zatrzymać krwawienie występujące przy obrzezaniu dzieci;

15) krwią chrześcijan żydzi leczą się z rozmaitych chorób, na które rzekomo tylko oni cierpią"9.

Badania przywołanego autora poświęcone były szczegółowemu rozważeniu takich zarzutów, zwłaszcza zaś drobiazgowemu wykazaniu bezzasadności każdego $\mathrm{z}$ nich $\mathrm{z}$ osobna $\mathrm{z}$ różnych punktów widzenia: z punktu widzenia rzeczywistych nakazów religii żydowskiej, która jak najsurowiej podobnych czynów zakazuje; z punktu widzenia zdrowego rozsądku itd. Zarówno w tych szczegółowych wywodach, jak i w ogólniejszych charakterystykach omawianych zarzutów i konkretnych historycznych przypadków ich występowania w cytatach ze źródeł historycznych itd. zawarty został i dostępny jest czytelnikowi dalszy jeszcze, obszerny materiał faktyczny, ilustrujący przedstawioną tu tezę o mnogości sposobów popełniania zabójstwa i pozostałych elementów przedstawianego rytuału.

Co mówią te fakty badaczowi?

Informują o dwóch rzeczach.

Po pierwsze, jakiemukolwiek historykowi, dzięki znanym każdemu z nich podstawom krytyki historycznej i oceny wiarygodności świadectw historycznych i bez potrzeby odwoływania się do samodzielnej refleksji czy nawet własnej przenikliwości, fakty te (to jest sama tylko wielopostaciowość i zmienność świadectw) mówią o podejrzanym charakterze tychże świadectw i ich niewiarygodności, informują o obecności czy to pierwiastka naiwnie legendarnego, czy też pierwiastka świadomego kłamstwa, sugerują nieodzowność surowej krytyki itd.

Informacja tego rodzaju nie jest nazbyt interesująca, a historyka, który by takie wnioski przedstawiał i na nich się skupiał, raczej byśmy nie mieli za szczególnie bystrego. Działając zgodnie ze zwykłą rutyną i szablonem badań historycznych, a przy niedostatku własnej przenikliwości okazałby on, nawet tego nie dostrzegając, wiele szacunku, nazbyt wiele szacunku badanym świadectwom

\footnotetext{
9 Tamże, s. 6 i nast.
} 
i oskarżeniom. Już sam historycznokrytyczny rozbiór każdego z takich oskarżeń $\mathrm{z}$ osobna jest przejawem nadmiernego dla nich szacunku.

Po drugie, fakty, o których mowa, dostarczają też wszakże niepomiernie istotniejszych, ważniejszych i bardziej interesujących informacji, które podważają sens i znaczenie poprzedniej, banalnej konstatacji.

Aby zrozumieć, o czym te fakty mówią, trzeba odłożyć na bok oskarżenia o zabójstwo „Z samej tylko nienawiści do chrześcijan” i oskarżenia o zabójstwa służące „do czarów, celów medycznych lub dowolnych innych przesądnych celów”, ponieważ zaciemniają one istotę faktów, przedstawiając je w sposób nieczytelny i mętny (jakkolwiek przydają znaczenia pierwszej, nie interesującej nas konstatacji). Szczególną uwagę należy zwrócić natomiast na zarzuty mordu rytualnego jako takiego (trzeba zaznaczyć, że takie i tylko takie zarzuty budzą zainteresowanie w dobie obecnej, pozostałe zaś oskarżenia o zabójstwa, podobnie jak dawniejsze oskarżenia żydów, tyczące się hostii, naczyń liturgicznych i inne, pomyślnie odesłano do archiwum historii). W odniesieniu zaś do mordów rytualnych, trzeba mówić nie o „celach”, ale o zachowaniach, będących wypełnieniem odpowiednich nakazów rytualnych.

$\mathrm{Z}$ tej racji należy przypomnieć i rozważyć, czym jest rytuał i jakie są cechy rytuału religijnego.

Rytuał, obrządek sakralny, z samej swojej natury ma charakter szablonowy i trwale niezmienny.

Polega na stałym i trwale niezmiennym wykonywaniu takich samych czynności nie tylko pod mistycznie religijnym rygorem nieważności całego aktu w razie jakiegokolwiek odstępstwa lub pominięcia któregokolwiek elementu, ale też pod rygorem poniesienia konsekwencji wynikających z grzeszności, religijnej występności takich naruszeń. Dotyczy to każdego rytuału religijnego, także prawosławnego, katolickiego itd., żydowskiego zaś tym bardziej, w wyjątkowym stopniu i w stanowczej formie. Ze względu na szczególne przyczyny historyczne (całkowicie zrozumiałe i nie wymagające objaśniania) u żydów mamy do czynienia z tak daleko idącym konserwatyzmem, lękliwością, detalicznym i szczegółowym fatalizmem, pedantyzmem przejawiającym się w dokładności i czystości akuratnego przestrzegania najdrobniejszych detali, jakich $\mathrm{w}$ innych religiach zapewne w ogóle nie da się odnaleźć.

I otóż, pośród rozmaitych pochodnych myśli ludzkiej, a ściślej - pośród rozmaitych pochodnych urojenia, wrogości i podłości ludzkiej istnieją i odgrywają zgubną rolę, niosąc jednym straszliwe nieszczęścia, innym zaś zatruwając i deprawując dusze, dzieła autorów, którzy silą się dowieść, że u żydów istnieje i działa swoisty dawny rytuał, że gdzieś, w jakichś średniowiecznych księgach znajduje się jego dokładny opis, mówiący, że polega on na tym to a na tym itd. Na dowód przytacza się większą lub mniejszą liczbę zapisków średniowiecznych kronika- 
rzy, zeznań kierowanych przez wychrzczonych żydów przeciwko współplemieńcom i byłym współwyznawcom, procesów i inkryminacji, tudzież podobnych świadectw. Gdyby w nie uwierzyć, tak jak wierzą (albo przynajmniej twierdzą, że wierzą) autorzy podobnych kompilacji materiałów antyżydowskich, to istotnie mogłyby być one uznane za dowód, ale nie tego, czego miały rzekomo dowodzić, ale czegoś wręcz przeciwnego. Po pierwsze, takie mniemane dowody godzą w samo rytualne urojenie i wyobrażenie, które wynieść może naiwny czytelnik, sądzący, że zostały one opisane szczegółowo w jakiejś, w rzeczywistości nieistniejącej, księdze. Po drugie, co ważniejsze i bardziej intersujące, zaprzeczają one rytualnemu charakterowi odnośnych zabójstw, o ile nawet w opisywanych przypadkach rzeczywiście dochodziło do zabójstw, dokonanych przez jakichkolwiek przestępców ${ }^{10}$.

W pierwszym przypadku swoistemu urojeniu i wyobrażeniu mniemanego rytuału przeczą same mniemane „dowody”, przedstawiane na jego potwierdzenie, a to dlatego że przedstawiają one sprawy zupełnie inaczej. W drugim przypadku tezie o rytualnym charakterze zabójstw zadaje kłam różnorodność sposobów pozbawiania życia i wszelkich okoliczności, co przeczy naturze rytuału religijnego, zasadzającej się na trwale niezmiennym wykonywaniu takich samych czynności. W konsekwencji można tutaj mówić o zabójstwach różnego rodzaju, ale akurat w żadnym wypadku nie o zabójstwach rytualnych, tym mniej zaś o żydowskich mordach rytualnych.

Wychodząc z tego, można stwierdzić, że różne dawne oskarżenia o zabójstwo „,z samej tylko nienawiści” czy też dla pozyskania specyfików medycznych były lepsze $\mathrm{z}$ tej choćby racji, że w odniesieniu do nich nie zostało naruszone podstawowe i elementarne prawo logiczne, jakim jest prawo sprzeczności (czy też niesprzeczności). Nawet oskarżenia o pozyskiwanie krwi do leczenia menstruacji u żydów płci męskiej, wyrastających im świńskich uszu, kłów itp. były lepsze, ponieważ przynajmniej nie naruszały podstawowego prawa ludzkiej logiki, mimo że były głupimi w swojej istocie produktami niewiedzy.

W przeszłości oskarżenia wobec żydów były proste. W czasach nowożytnych podejrzenia i oszczerstwa wyrażane są zazwyczaj w bardziej wyrafinowanej formie. Wydają się mniej odrażające, a przy odpowiednim sposobie przedstawienia

${ }^{10}$ Wielokrotnie były popełniane i wykrywane przestępstwa, inne jednak niż zabójstwo: podrzucanie żydom na przykład ekshumowanych zwłok, niepogrzebanych ciał samobójców, topielców (towarzyszyło temu niekiedy takie preparowanie zwłok, aby odpowiadały one przyjętemu wariantowi legendy), fałszywe zeznania świadków, fałszerstwa itd. 
- skromne i nieszkodliwe, choć efekt ich oddziaływania na niewykształcone masy itp. pozostał taki sam. Nie wszyscy zatem żydzi bez wyjątku, a jedynie sekta. Wszak istnieją rozmaite, niekiedy nawet fanatyczne sekty nawet pośród chrześcijan, czemu więc żydzi mieliby być lepsi? I tak, w różnorakich oszczerczych i szarlatańskich pracach prezentowany jest stosowny zestaw dowodów, sugerujących ideę takiej sekty.

Taki sposób budowania oskarżeń został już poddany szczegółowej, w pełni jasnej i przekonywającej krytyce, a następnie obalony we wspominanym wcześniej studium profesora Chwolsona. Autor powtórzył swoją krytykę, w skróconej formie, w broszurze Upotrieblajut li jewriei christianskuju krow ${ }^{1112}$, a następnie raz jeszcze w formie krótkiego résumé podstawowych argumentów w artykule polemicznym, wydanym ostatnio jako dodatek do wspomnianej broszury. Ze względu na klarowność wywodu, jego przekonujący charakter oraz wyjątkowo syntetyczną formę wydaje mi się dopuszczalne przytoczenie wspomnianego résumé:

„Powtórzę tu w krótkich słowach to, o czym pisałem gdzie indziej. Żydzi, jak stwierdziłem, zawsze negowali i nadal negują istnienie pośród nich takiej sekty, w całej zaś literaturze żydowskiej nie ma nawet śladu jej istnienia, co przyznają nawet najbardziej zatwardziali wrogowie żydów. Mamy zatem dwie możliwości: bądź żydzi rzeczywiście nie wiedzą o istnieniu w ich środowisku sekty, bądź też wiedzą o niej, ale milczą i nawet bronią odrażających sekciarzy. Obydwie ewentualności są jednakże równie niemożliwe. Pierwsza dlatego, że przez całe trwanie wieków średnich, a gdzieniegdzie nawet do czasów najnowszych żydzi żyli ciasno stłoczeni w wydzielonych dzielnicach, nazywanych gettami, zasiedlając wąskie i gęsto zabudowane ulice. Jeśliby wśród nich działała sekta albo poszczególne osoby, które by rokrocznie albo co najmniej po wielokroć wykradały i zabijały chrześcijańskie dzieci, to dla pozostałych żydów nie mogłoby to pozostawać tajemnicą przez z górą 500 lat, zwłaszcza wobec powtarzających się oskarżeń i idących za nimi okrutnych prześladowań, dających wystarczający powód poszukiwania takich złoczyńców. Założenie, że żydzi wiedzieli o istnieniu takiej sekty i umyślnie to przemilczali, jest równie niemożliwe, żydzi bowiem, co zostało wystarczająco udowodnione historycznie, na przestrzeni swej historii prześladowali każdą pojawiającą się między nimi sektę, niezależnie od tego, w jakich, choćby mało istotnych, punktach od-

${ }^{11}$ A[wraamowicz] Chwolson, O niekotorych sriedniewiekowych obwinienijach protiw jewriejew..., s. 360 i nast.; tenże, Upotrieblajut li jewriei christianskuju krow, wyd. 3, Tip. P.K. Lubkovskogo, Kijew 1912, s. 29 i nast. [Czy żydzi używaja krwi chrześcijańskiej].

${ }_{12}$ Przywoływana w przypisie broszura Chwolsona powstała w latach osiemdziesiątych XIX wieku i miała wówczas dwa wydania w Sankt Petersburgu. W Kijowie została wydana rok po śmierci autora, zapewne w związku z zainteresowaniem toczącą się sprawą Bejlisa [przyp. tłum.]. 
chodziła ona od pnia judaizmu, co więcej - prześladowali wszystkimi możliwymi środkami i przy pomocy wladz świeckich. Dlaczego akurat w odniesieniu do tak odrażającej sekty, która poprzez wieki była przyczyną tak wielu nieszczęść dotykających żydów w całej Europie, mieliby nie tylko być tolerancyjni, ale wręcz wyjątkowo jej sprzyjać? Dlaczego ze wszystkich sił starali się bronić oskarżanych, a nawet uwiecznili w modlitwie pamięć tych, którzy wskutek oskarżeń stali się męczennikami? Dlaczego po dziś dzień szlachetni synowie Izraela, tacy między innymi, jak Crémieux czy Mojżesz Montefiore, uważają za swój święty obowiązek na miarę sił swoich wstawiać się za żydami, oskarżanymi o używanie krwi chrześcijańskiej?"’3.

Zdać by się mogło, że każdy obiektywny, otwarty na logikę i argumenty człowiek powinien uznać siłę i wiarygodność takich wyjaśnień. Najwyraźniej jednak nie są one wystarczające. Tak jak w kamiennych ścianach potężnie ufortyfikowanych twierdz nie wystarczy uczynić jedną wyrwę, a trzeba ich uczynić jak najwięcej, tak w pewnych okolicznościach przesądy nie poddają się nawet takim ciosom logiki, które w innych okolicznościach wystarczyłyby do rozbicia podobnych owoców fantazji.

Mając to na uwadze, trzeba zaznaczyć, że wskazane wyżej (rozdz. II, III i IV) argumenty, z samej swej natury, równie dobrze stosują się do obydwu form krwawego oszczerstwa.

Ponieważ nie idzie tutaj o incydentalne, indywidualne przestępstwa, ale o rytuał religijny, o obowiązujące i przestrzegane normy sakralne, niezależnie zatem od tego, czy będziemy mówić o całym narodzie czy o jego części, nieuchronnym skutkiem będzie to, o czym mówiłem w rozdziale II i III, tyle tylko że w mniej znaczącej skali, być może nie we wszystkich krajach, w których żyje mniejszość żydowska, ale w każdym razie tam, gdzie istnieje i działa sekta itd. Tak czy inaczej, musiałoby dochodzić do zdarzeń, do których w rzeczywistości nie dochodzi.

Ponieważ nie idzie tutaj o pospolite, indywidualnie zróżnicowane przestępstwa, ale o rytuał religijny, a zatem o niedopuszczający odchyleń szablon, jawnie niedorzeczne i sprzeczne wewnętrznie jest przywoływanie na dowód faktów, które samą swoją wielobarwnością i różnorodnością zaprzeczają istocie rytuału, niezależnie od tego, czy są odnoszone do żydów jako takich czy do „sekty”. Jeśli jest tu jakaś różnica, to zawiera się ona tylko w dodaniu drugiej sprzeczności wewnętrznej, polegającej na tym, że rozmaite relacje, odnoszące się do żydów w ogólności - teksty żydowskie, świadectwa wychrzczonych, nie należących do sekty Żydów, dotyczące ich byłych współwyznawców, opisy zwykłych i nienależących do sekty żydów itd. - są przywoływane do udowodnienia tezy o sekcie,

\footnotetext{
${ }^{13}$ A[wraamowicz] Chwolson, Upotrieblajut li jewriei ..., s. 67- 68.
} 
która sama przez się zaprzecza tymże, uznawanym za wiarygodne, ogólnym dowodom. Już lepiej trzymać się pierwotnej formy oszczerstwa, mniej przebiegłej, ale też mniej nielogicznej i mniej sprzecznej wewnętrznie.

Przyjmijmy jednak to, co zgodnie z powyższym jest absurdem, czymś absolutnie niemożliwym i niewiarygodnym. Przyjmijmy więc, że istnieje żydowski rytuał, że rokrocznie dochodzi do zgodnych z nim zabójstw dzieci chrześcijańskich, jakimś cudem nie dających się wykryć, a nawet dostrzec, niewidocznych dla rodziców, otoczenia, prasy, statystyk itd.

Przyjmijmy jeszcze, że rany zadane chłopcu zabitemu w Kijowie odpowiadają zamysłowi pozyskania krwi, więcej nawet, że rany te (jakkolwiek zadane przez odzież, co prowadzi do ubytków i zanieczyszczenia puszczanej krwi) ściśle odpowiadają wymogom wyobrażonego rytuału. Oznaczałoby to ujawnienie mordu rytualnego, co byłoby odkryciem o randze światowej, pierwszym w historii wykryciem autentycznego przypadku rytuału (w odróżnieniu od wszystkich wcześniejszych rytualnych procesów i oskarżeń, w których szło o coś innego, takiego bowiem typu i formy zabójstwa nie stwierdzono).

Wszystkie takie (przyjęte tu warunkowo) założenia są niezbędne do tego, byśmy mogli nadal z powagą rozważać okoliczności, widząc je z perspektywy mordu rytualnego (są one tym bardziej niezbędne do oskarżenia).

Mało tego, stwórzmy jeszcze dla tego przypadku dogodną dla strony skarżącej zasadę wymiaru sprawiedliwości, zgodnie z którą można i należy skazywać mimo braku jakichkolwiek poważnych dowodów winy, chyba że strona przeciwna bezspornie udowodni niewinność oskarżonego.

Byłaby to zasada absurdalna i niegodziwa. Nawet najcnotliwszym ludziom zazwyczaj trudno byłoby bezspornie wykazać swoją niewinność, żądanie zaś tego od oskarżonych jest żądaniem niegodziwym. Gdyby żądano ode mnie dowodów, że nikogo nie zabiłem, nie okradłem itp., nie podjąłbym się tego i powiedziałbym: jeśli takie są wasze zasady wymierzania sprawiedliwości - cóż zrobić, skazujcie!

Bywa jednak, że dzięki wyjątkowemu zbiegowi sprzyjających okoliczności można skutecznie zmierzyć się z takimi nawet zasadami, zakładając jedynie, że będzie się mieć do czynienia z ludźmi pozostającymi w innych kwestiach „przy zdrowych zmysłach i dobrej pamięci".

Właśnie taki szczęśliwy zbieg nastąpił podczas kijowskiego procesu o mord rytualny. W szczególności, dzięki wyjątkowo sprzyjającemu zbiegowi okoliczności, możliwe jest wykazanie za pomocą pewnych względnie prostych wywodów, że zabójstwo, będące przedmiotem procesu, może mieć dowolny charakter, z wyjątkiem rytualno-żydowskiego. 
Aby to wyjaśnić i w ogóle właściwie zrozumieć omawianą sprawę karną, trzeba przede wszystkim zwrócić uwagę na to, jak przestępcy postąpili ze zwłokami ofiary po popełnieniu zabójstwa.

Sprawcy nie spalili zwłok, choć prawdopodobnie dysponowali odpowiednim paleniskiem, nie zakopali ich $\mathrm{w}$ ziemi, nie wrzucili w worku obciążonym kamieniami do wody itp. Zamiast tego pozostawili je w miejscu odwiedzanym przez dzieci, żebraków, włóczęgów itd., rozrzuciwszy przy tym wokoło przedmioty przyciągające uwagę przechodniów. Co więcej, ułożyli zwłoki tak, aby liczne rany kłute i pozostałe ślady dokonanego czynu nie tylko były na nich widoczne, ale nawet rzucały się w oczy, nie podejmując jakichkolwiek, oczywiście możliwych, jeśli byłaby taka wola, prób zatarcia i ukrycia śladów tego rodzaju.

Osobom mającym wyobraźnię już tego wystarczy, by dojść do wniosku, że zabójstwo to w żadnym wypadku nie ma charakteru żydowskiego mordu rytualnego.

W rzeczy samej, czy to możliwe, żeby żydzi, zabiwszy chłopca w celach rytualnych, zrobili ze jego zwłokami to, co z nimi faktycznie uczyniono? Czy to możliwe, żeby wystawili zwłoki, by tak rzec, na pokaz dzieciom, żebrakom i innym osobom odwiedzającym miejsce, w którym je pozostawiono, a zatem całemu światu, i to jeszcze z zachowaniem znamion rytuału, tak by cały świat dowiedział się o mordach rytualnych!

W taki sposób postąpić by mogli nie żydzi, oddani swojej religii i swojemu ludowi, ale przeciwnie - głęboko fanatyczni wrogowie żydów.

Jest rzeczą zrozumiałą, że mordy rytualne, gdyby istniały, absolutnie wykluczałyby takie traktowanie zwłok. W ich przypadku, inaczej niż w różnorakich innych odmianach i przypadkach zabójstw, kiedy przestępcy zależy jedynie na tym, aby nie zostać wykrytym, uratować siebie samego i na niczym więcej, oczywistym, wyjątkowo ważnym i jasnym dla każdego sprawcy zadaniem byłoby ukrycie śladów uczynku, najlepiej zaś unicestwienie zwłok przez spalenie, albo co najmniej ukrycie śladów wskazujących na sposób dokonania zabójstwa oraz samych zwłok, by nie ujawniać nie tylko udziału określonych osób, ale też samego przestępstwa, sposobu jego dokonania i cech charakterystycznych.

Skądinąd także w wielu innych odmianach i przypadkach zabójstw oraz innych przestępstw wyjątkowo ważne dla wyjaśnienia sprawy jest zwrócenie uwagi zarówno na to, co przestępca ukrywał, jak i na to, czego nie ukrywał, bo nie uważał tego za niezbędne. Już samo to może prowadzić do cennych spostrzeżeń i wiele wyjaśniać. Gdyby zdarzyło mi się pisać podręcznik dla śledczych sądowych itp., to opracowałbym te właśnie kwestie jak najskrupulatniej, nadając im rangę ważnych wytycznych o charakterze ogólnym. W omawianej tu sprawie, ze względu na samą jej naturę, ten aspekt ma odrębne i szczególne, wyjątkowo ważne znaczenie. Bardzo mnie dziwi, że w trakcie zarówno postępowania 
wstępnego, jak i samego śledztwa sądowego roztrząsano i roztrząsa się przeróżne drobiazgi, rozliczne kwestie i zagadki, w ogóle nieważne albo pozostające bez żadnego związku ze sprawą, a do tego, oczywiście kardynalnego, aspektu sprawy nie przywiązuje się żadnej wagi.

Mało tego - oskarżenie Bejlisa opiera się na tym, jakoby on w obecności jakichś świadków pojmał i uprowadził swoją ofiarę.

Tak więc Bejlis przy świadkach pojmał i uprowadził ofiarę przeznaczoną na mord rytualny, potem zaś, aby nie pozostawiać zakłopotanych świadków w niepewności co do powodu, dla którego ofiara została pojmana, zwłoki ze śladami wszystkiego, co chłopcu uczyniono, pozostawił w miejscu uczęszczanym przez tych samych świadków, a także różnych innych ludzi.

Ale przecież to niedorzeczne! Do tego stopnia niedorzeczne, że pojawia się pytanie o poziom zdolności umysłowych i w ogóle o to, czy przy zdrowych zmysłach i dobrej pamięci pozostaje ten, kto skłonny byłby w coś takiego uwierzyć lub też ten, który tak by postąpił.

Jeżeli Bejlis istotnie tak by właśnie postąpił, to świadczyłoby to o tym, że człowiek ten postradał zmysły i powinien zostać doprowadzony nie na ławę oskarżonych, ale do szpitala w celu określenia jego kondycji psychicznej itd.

Ponadto należałoby zatroszczyć się o wyszukanie w okolicy, pojmanie i umieszczenie w szpitalu psychiatrycznym także pozostałych obłąkanych żydów. Należałoby bowiem przyjąć, że także współsprawcy, rzec by można, dla kompanii, pospołu zmysły postradali.

Rozumie się samo przez się i nietrudno, jak się zdaje, to sobie wyobrazić, że chłopiec, który został pojmany i uprowadzony przez żydów przy świadkach, z samej tej przyczyny stałby się absolutnie nieodpowiedni do roli ofiary mordu rytualnego i taka okoliczność gwarantowałaby mu bezpieczeństwo nawet wówczas, gdyby mordy rytualne faktycznie istniały i były praktykowane.

Oficjalni i nieoficjalni stronnicy oskarżenia starali się i starają dowieść „faktu”, że Bejlis pojmał itd. Przedstawiciele obrony działają w przeciwnym kierunku. Daje to takie wrażenie, jakby zamieniono się rolami: przedstawiciele oskarżenia podejmują wysiłki na rzecz zaprezentowania swego oskarżenia w sposób niedorzeczny i śmieszny, natomiast strona przeciwna troszczy się o to by temu przeszkodzić1 ${ }^{14}$.

${ }^{14}$ Można nadmienić, że pośród najróżnorodniejszych odnoszących się do krwawego rytuału indywidualnych urojeń, skomplikowanych i wzbogaconych rozlicznymi dodatkowymi niedorzecznościami, znajdziemy i takie, zgodnie $\mathrm{z}$ którymi cechą rytuału ma być jawne i demonstracyjne wystawienie zwłok, z zachowaniem nakazanych rytuałem śladów i wyżej wspomnianych operacji, mające na celu poinformowanie chrześcijan. Jest to wyjątkowo niedorzeczna i niefortunna postać krwawego oszczerstwa. W szczególności, nawet najbardziej ograniczeni ludzie bez trudu dojdą do wniosku, że jest to niewiarygodne z samej tylko tej racji, że znajdowano by wiele zwłok ze śladami ran zadawanych $\mathrm{w}$ jeden $\mathrm{i}$ ten sam sposób, ściśle odpowiadający prezentowanemu przez twórcę 
W każdym razie, konkluzje nakazują stwierdzić, co następuje. Nie uzasadniono oskarżenia, nie dowiedziono (non liquet) jego prawdziwości i solidności. Dysponujemy czymś więcej niż tym, co niepodważalnym i powszechnie uznanym zasadom wymiaru sprawiedliwości wystarcza do uniewinnienia, oczywisty jest tu bowiem brak winy, wynikający z niepodobieństwa tego, co stanowi treść oskarżenia, a nawet jego sprzeczność z prostym, zdrowym rozsądkiem. Jeśli nawet przyjąć niedorzeczne, jak wynika z powyższego, generalne założenie o istnieniu krwawego rytuału u żydów itd., to w omawianym przypadku nie da się o nim mówić. Może to być zabójstwo każdego rodzaju, ale w żadnym razie akurat nie żydowski mord rytualny.

Można to ująć jeszcze inaczej. Jeśli zignorować naukę i zdrowy rozsądek, a oprzeć się na pospolitym przesądzie o posługiwaniu się przez żydów krwią chrześcijańską, to można, z mniejszym lub większym powodzeniem, budować odpowiednie, konkretne oskarżenia odnoszone do najróżniejszych przypadków śmierci dzieci, i to nie tylko zadanej przemocą, ale też nie zadanej w taki sposób, a nawet do tych, w których dziecko pozostaje przy życiu, jeżeli brak na ten temat informacji, jeżeli nie wiadomo, co się z dzieckiem stało. Ale akurat nie w tym wypadku. Ten bowiem, ze względu na swoją szczególną naturę, akurat wyjątkowo i całkowicie się do tego nie nadaje.

\section{VII}

Uważam za konieczne zwrócenie szczególnej uwagi na tę okoliczność, że moje wywody, co wynika z powyższego, opierają się wyłącznie na tym, co zawiera i twierdzi akt oskarżenia i, szerzej, na tym, na co się powołują i co prezentu-

takiej wersji, a żydzi, rokrocznie demaskujący swój lud, niepoczytalnie działając na jego nieszczęście i zgubę, nie mieliby możliwości odżegnywać się od krwawego oszczerstwa i argumentować przeciwko niemu itd. Zazwyczaj legenda o mordach rytualnych wolna jest od takiego dodatkowego absurdu. Przeciwnie, w takich legendach i w odnośnej literaturze wskazuje się i podkreśla chytrość żydów oraz ich umiejętności ukrywania i zacierania śladów. Tylko na takiej podstawie możliwe jest wpieranie odpowiednich przekonań, choćby nawet tylko niedouczonej i przesądnej gawiedzi. Idąc tym tropem, moją argumentację (rozdz. II i nast.) odnosiłem do takiego właśnie, w literaturze przedmiotu powszechnie przyjętego stanowiska, ignorując dodatkową, zupełnie naiwną i odosobnioną niedorzeczność, zakładającą demonstrowanie chrześcijanom rytuału za pomocą zwłok. Na identycznej podstawie za zbędne uznałem odrębne rozważanie wiążącej krwawy rytuał specjalnie z chasydami wersji, świadczącej, poza wszystkim, o niewiedzy w zakresie historii lub o bezczelności twórców i zanegowanej przez same już historyczne dane dotyczące czasu powstania tej „sekty”. $\mathrm{Z}$ zasady nie brałem pod uwagę i nie prezentowałem rozmaitych dodatkowych niedorzeczności, podobnie jak i różnorodnych indywidualnych urojeń. Było by to zarówno niepotrzebne, jak i trudne do przeprowadzenia, a to ze względu na wielorakość tych nonsensów. Zaznaczę tylko, że przy całej rozmaitości indywidualnych niedorzeczności w tej dziedzinie takich wersji, zgodnie z którymi uprowadzenie zachodziłoby jawnie, w obecności chrześcijańskich świadków, mimo wszystko nie spotkaliśmy. Czegoś takiego jeszcze nikt nie wymyślił. 
ją stronnicy oskarżenia. Mógłbym przywołać wiele innych argumentów idących w tym kierunku, uzasadnić za pomocą mniej lub bardziej prostych wywodów niewątpliwą wiarygodność przywoływanych danych, wysnuć odpowiednie wnioski itd. Świadomie jednak i rozmyślnie powstrzymałem się od tego, choć bardzo interesujące wydawałoby się zatrzymanie na niektórych dodatkowych danych.

Idzie tu po części o takie okoliczności, które stronnikom oskarżenia są zupełnie nie w smak, które tak bardzo im się nie podobają i drażnią, że dochodzi do scen nie licujących nie tylko z pryncypiami i godnością wymiaru sprawiedliwości, ale też z elementarnymi zasadami ludzkiej etyki, przyzwoitości i taktu. Po części idzie zaś o okoliczności, które jak dotąd, nie przyciągają szczególnej uwagi i nie wzbudzają silnych namiętności, są jednak przywoływane przez świadków nielubianych, podejrzewanych o krzywoprzysięstwo i będących obiektami obraźliwych zaczepek i przykrych scen. Do tego kręgu zaliczani są także świadkowie oskarżenia, pozyskani w różnych środowiskach, by wzmocnić oskarżenie, o ile mówią rzeczy zbędne, nie zaś to, co trzeba.

Tak właśnie, świadomie i rozmyślnie, opierałem swoje wywody wyłącznie na tym, co było po myśli stronnikom oskarżenia, co było przez nich podtrzymywane i co całkowicie wyklucza jakąkolwiek możliwość podjęcia dyskusji na temat żydowskich wpływów, nacisku na świadków itd. Można założyć, jeśli ktoś uważa to za możliwe, że wszyscy wspomniani świadkowie, niezależnie od ich pokaźnej liczby i znacznego zróżnicowania pozycji społecznej, kondycji umysłowej, przekonań religijnych i innych, to zatwardziali przestępcy, składający kłamliwe zeznania pod przysięgą itp., a mimo to mój wywód pozostanie niezachwiany i zupełnie nawet nienaruszony ${ }^{15}$.

${ }^{15}$ Nawiasem mówiąc, pominąłem także rozmaite okoliczności, dowodzące nierytualnego charakteru zabójstwa, które nie dają podstaw do podobnych dyskusji. Weźmy choćby narzędzie, którym, sądząc po ranach dokonano zabójstwa: szydło, dłuto czy coś podobnego. Każdy może łatwo sobie wyobrazić przestępcę - specjalistę w zakresie kradzieży z włamaniem do różnych pomieszczeń, noszącego w kieszeni takie narzędzie. Ale wyobrażenie sobie kapłana, spełniającego religijną ceremonię ofiarowania czy też upuszczenia krwi, wyposażonego w tym celu w szydło albo dłuto, łatwo przyjdzie jedynie wyjątkowo niemądremu człowiekowi, bo już choćby średnio wykształcone$\mathrm{mu}-\mathrm{z}$ trudem, nie mówiąc już o kimś, kto dysponuje choćby pewnym wykształceniem w zakresie historii i psychologii religii, kultów, składania ofiar itd., dla niego będzie to bowiem jawny absurd.

Charakter narzędzia mówi o tym, że przestępstwo zostało popełnione w nieodpowiednich warunkach i bez należytego „rytuału” itp., ale też bez jakiegokolwiek w ogóle przygotowania, nagle, dla szybkiego wykorzystania nadarzającej się okazji jego popełnienia, za pomocą pierwszego lepszego albo noszonego w kieszeni narzędzia. I oczywiście zostało ono popełnione nie przez „rabina”, „cadyka” itp., ale przez przestępcę specjalizującego się w kradzieżach z włamaniem (albo, co nie mniej wiarygodne, przez rzemieślnika).

Pozycja ofiary w trakcie zadawania ran (stojąca, co wynika z ran i śladów krwi), udowadnia ze swej strony nierytualny charakter zabójstwa już choćby dlatego, że krew z takich ran nie mogła spływać do naczynia z przyczyn fizycznych, natomiast nieuchronnie musiała spływać i spływała po ciele ofiary. Zadanie ran w głowę przez czapkę jest kolejnym dowodem. 
A doszedłem do tego wywodu, nie bacząc na to, że dopuściłem, idąc po myśli oskarżenia, cały szereg założeń jemu niezbędnych - nie tylko wcale nie udowodnionych, ale wręcz niedorzecznych, takich które powodują, że same tylko racje zdrowego rozsądku świadczą o oczywistości czegoś wręcz przeciwnego.

Oskarżenie stanowi wielopiętrową konstrukcję myślową, w której każda kondygnacja zbudowana została z surowców umysłowych uderzająco niskiej jakości. Nie podejmę się dokonania całościowej oceny gmachu jako zbioru poszczególnych elementów. Trudno by było znaleźć i wyrazić w formie literackiej odpowiednią charakterystykę, choćby miała się ona odnosić tylko do intelektualnego aspektu sprawy.

\section{VIII}

„Jak więc w takim razie wyjaśnić te dziwaczne rany kłute, zbędne i osobliwe z punktu widzenia zwyczajnego zabójstwa?’. Pytanie takie nie raz dawało się słyszeć w tej lub innej formie, i to nawet od osób, których intelektualna i moralna sylwetka zasadniczo wyklucza stawanie po stronie krwawego oszczerstwa. W ich ustach stanowi ono poboczną refleksję, która co prawda nie może zachwiać przekonaniem o słuszności racji przeciwników krwawego oszczerstwa, niemniej zakłóca poczucie pewności. W ustach osób umysłowo i moralnie niżej stojących, tym bardziej zaś u osób o psychice nienawistnej i oszczerczej ma ono oczywiście inny, zdecydowanie bardziej złośliwy charakter.

Celowe wydaje mi się przedstawienie własnego poglądu w tej kwestii.

Czyż gazety nie dostarczają nam bez liku wiadomości o różnorakich, wielce zagadkowych i niewyjaśnionych przestępstwach? Nie udzielają nam natomiast bardziej nawet gorzkich niż te wiadomości o przestępstwach, dodatkowych informacji o tym, że ze względu na niemożność wyjaśnienia do wypełnienia i przykrycia takiej luki informacyjnej zostały aresztowane i postawione przed sądem dowolne, przypadkowo schwytane osoby, by wzięły na siebie ciężar wyjaśnienia sytuacji i wykazania tym swojej niewinności. Przeciwnie, zazwyczaj dowiadujemy się, że trwa energiczne śledztwo itd. W większości przypadków następuje potem, dzięki właściwym działaniom odnośnych organów władzy, fortunne wykrycie i zdemaskowanie winnych oraz wyjaśnienie przestępstwa.

W odniesieniu do niniejszych uwag dyskusje o świadkach i ich sprzedajności również są wykluczone. Jednakże dla mojego, tu przedstawionego wywodu uwagi takie są zbędne, w pełni wystarczy zaś to, co wyjątkowo odpowiada stronnikom oskarżenia i jest przez nich podnoszone, a zatem, jak się zdaje, przeciwko czemu z ich strony nie ma i nie może być żadnych obiekcji. Trzeba zaznaczyć, że kuriozalnie akurat „szydło” jako narzędzie rytuału i wyposażenia „cadyka” wyjątkowo odpowiada rzecznikom oskarżenia. 
Niekiedy jednak sprawa pozostaje niewyjaśniona i tajemnicza, ale z tego powodu nikogo nie pociąga się do odpowiedzialności i nie wysnuwa się wniosków o czyjejkolwiek winie. Odpowiada to pryncypiom wymiaru sprawiedliwości i zdrowemu rozsądkowi.

Jednakże w omawianym tu przypadku o ,niewytłumaczalności” nie może być nawet mowy. Można mieć do czynienia z nią, gorzej nawet, z nagromadzeniem nie tylko niewythumaczalnych, ale i niewyobrażalnych elementów tylko pod warunkiem uporczywego objaśniania sprawy z perspektywy rytualnej legendy. Jeśli zdjąć te ciemne, zupełnie czarne i niedopuszczające światła okulary, to i niewythumaczalność znika.

Mało tego, ci którzy w najmniejszym choćby stopniu są zaznajomieni ze zjawiskami przestępczości, dysponowaliby w pełni dostatecznym do wyjaśnienia sprawy materiałem nawet w sytuacji, w której szczegółowe i konkretne wskazówki nie wynikałyby z okoliczności sprawy.

W takim wypadku (to znaczy przy braku bardziej szczegółowych wskazówek) pozostałyby do dyspozycji następujące, przykładowo, objaśnienia, możliwe do przyjęcia, naturalne i zdecydowanie lepsze niż przedstawione wyżej kombinacje rytualne:

1. Dążenie przestępcy do nadania przestępstwu niezwykłej formy po to, aby wydawało się ono publiczności bardziej zagadkowe i zaprowadziło ją na manowce (niekoniecznie rytualne), ponieważ w przeciwnym wypadku łatwo można by dojść do rzeczywistych źródeł i natury przestępstwa. W takiej sytuacji bardziej celowe może być, czy choćby się wydawać, nie ukrycie, lecz wystawienie zwłok na widok publiczny.

2. Symulacja, w tym samym celu, cech mordu rytualnego, opierająca się na zasłyszanej legendzie, agitacji albo poduszczeniach.

3. Symulacja mordu rytualnego w zamiarze przygotowania pogromu albo w innym celu (tak jak to nie raz się zdarzało w przeszłości).

4. Umyślnie okrutne zabójstwo, zaplanowane jako zemsta za rzeczywiście uczynione albo domniemane zło, na przykład za donoszenie zwierzchności o innych przestępstwach szajki.

5. Zwyczajne zabójstwo popełnione w takim czy innym celu, rozpoczęte spokojnie i z zimną krwią, a następnie, jak to często bywa, przechodzące (zgodnie ze znanym, tu nie omawianym prawem psychologicznym) we wściekłe i chaotyczne zadawanie zbędnych już ran itd.

6. Zadawanie licznych ran w różnych miejscach ciała ze względu na niezdatność narzędzia, niedostatek wykształcenia przestępcy w zakresie anatomii i fizjologii oraz niepewność co do śmierci ofiary.

Gdzie tu jest miejsce na poważną dyskusję o niewytłumaczalności, jeśli mamy do czynienia z przeciwną niż mord rytualny ewentualnością! 
W omawianej sprawie, bez względu na wszystkie komplikacje utrudniające pełne jej wyjaśnienie, dostępne są wszakże rozmaite dane, pozwalające, jeśli je zastosować odpowiednio, przejść drogę od niewytłumaczalności do wyjaśnienia.

Ponieważ celem mojego artykułu nie jest oskarżanie i demaskowanie kogokolwiek, ale stanowcza obrona cierpiących niewinnie przez przesądne i przerażające krwawe oszczerstwo oraz usilne działanie na rzecz zapobieżenia czy choćby tylko osłabienia grożących w przyszłości, niewspółmiernie groźniejszych, związanych z tym nieszczęść i cierpień niewinnych ludzi, nie wydaje mi się ani niezbędne, ani stosowne przedstawianie kolejnych jeszcze moich opinii związanych z wykryciem i wyjaśnieniem tego przestępstwa. 